\title{
The Influence of Organizational Culture and Organizational Commitment on Employee Performance at the Ministry of Manpower of the Republic of Indonesia
}

\author{
E. Nurzaman AM \\ Pamulang University, Banten, Indonesia \\ warek1@unpam.ac.id
}

\begin{abstract}
This study aims to determine the effect of organizational culture and organizational commitment on employee performance at the Ministry of Manpower of the Republic of Indonesia. The method used is explanatory research with analysis techniques using statistical analysis with regression testing, correlation, determination and hypothesis testing. The results of this study that organizational culture has a significant effect on employee performance by $38.3 \%$, hypothesis testing is obtained $t$ count $>t$ table or (7.757 > 1.985). Organizational commitment has a significant effect on employee performance by $41.7 \%$, hypothesis testing is obtained $t$ count $>t$ table or $(8.335>1.985)$. Organizational culture and organizational commitment simultaneously have a significant effect on employee performance with the regression equation $Y=9.612+0.326 X 1+0.442 X 2$. Contribution of influence is $51.7 \%$, hypothesis testing obtained $F$ count $>F$ table or (51.364>2,700).
\end{abstract}

Keywords

organizational culture; organizational commitment; employee performance

\section{Introduction}

Human resources are the factors that determine the success of an organization/agency/company. Human resources who have high performance will support the success of achieving the goals of the organization / agency / company. However, companies / agencies often face problems related to employee performance. Therefore, companies / agencies need to pay attention to the factors that can affect the performance of their employees.

Human resource development is an effort to develop the quality or ability of human resources through the process of planning education, training and management of personnel or employees to achieve an optimal result (Notoatmodjo in sulasmi, 2020). The development of human resources through the cultivation of achievement motivation is one of the contributions in improving the quality of human resources. (Werdhiastutie et al, 2020)

Sulasmi (2020) states that Human resources are potentials and are assets and function as capital (non-material / non-financial) in the organization, which is realized as physical and non-physical potential in realizing the existence of the organization.

According to Mangkunegara (2011: 67), job performance is the quality and quantity of work achieved by employees in carrying out their duties according to the responsibilities assigned to them. Individual employee performance will affect the overall company performance. The higher the employee's performance, the higher the performance of the company where the employee works.

Organizational culture develops easily even in an organization that is full of people who have different cultural and educational backgrounds. Organizational culture should be able to 
be used as part of a strategy or way of improving performance. Organizational culture has a positive influence on employee performance (Widodo, 2010). This shows that the better the organizational culture in a company, the better the employee's performance in the company. Organizational culture can shape the personality and habits of employees. These personalities and habits will shape employee behavior in doing work which will ultimately determine the employee's performance.

Organizational culture is a set of assumptions or systems of beliefs, values, and norms developed in organizations that serve as guidelines for behavior for its members to overcome the problem of external and internal adaptation. Organizational culture is a pattern of beliefs and organizational values that are believed and imbued by all members in doing work as an appropriate way to understand, think, and feel about related problems, so that it will become a value or rule within the organization. This will encourage members of the organization to work harder and create work motivation (Mangkunegara in Arif, 2019).

Organizational commitment has a great influence on the performance of organizational members or employees of a company (Tolentino, 2013). Employees who have a high organizational commitment are employees who prioritize the interests of the organization rather than their own interests, so that these employees tend to work optimally and have good performance.

The Ministry of Manpower of the Republic of Indonesia is required to always have a good performance in carrying out its main duties and vital functions related to manpower in the Republic of Indonesia. The less than optimal performance of the Ministry of Manpower of the Republic of Indonesia can hinder the development and development of quality human resources in Indonesia. Therefore, the Ministry of Manpower needs to constantly improve the performance of its employees in order to improve the overall performance of its agency.

Based on this background, research is necessary to examine and analyze the influence of organizational culture and organizational commitment on the performance of employees of the Ministry of Manpower of the Republic of Indonesia.

\section{Research Methods}

\subsection{Population}

Population is a set of objects that are determined through certain criteria which will be categorized into the object to be studied. According to Sugiyono (2016) defining population is the number of generalization areas consisting of objects or subjects that have the qualities and characteristics set by the researcher and then draw conclusions. The population in the study was 99 respondents from the Ministry of Manpower of the Republic of Indonesia

\subsection{Sample}

According to Sugiyono (2016), namely "The sample is the number and characteristics of the population". Meanwhile, Suharsini Arikunto (2010) argues that "The sample is part or representative of the population under study". The sampling technique in this study was saturated sample, where all members of the population were sampled. Thus the sample in this study amounted to 99 respondents.

\subsection{Types of Research}

The type of research used is associative, where the goal is to find out how to find a connection between. 


\subsection{Data Analysis Methods}

According to Sugiyono (2016), "The research model is a synthesis that reflects the relationship between the variables studied and is a guide to solving research problems and formulating hypotheses in the form of a flowchart equipped with qualitative explanations". In this study the research model created as follows: In analyzing the data used instrument test, classical assumption test, regression, coefficient of determination and hypothesis testing.

\section{Discussion}

\subsection{Instrument Test}

In this test used the validity test and reliability test. The validity test is intended to determine the accuracy of the data regarding the suitability between what is being measured and the measurement results. According to Sugiyono (2016) "Valid means that there is a similarity between the collected data and the real data". Meanwhile, Ghozali (2013) argues that "A questionnaire is said to be valid if the questions on the questionnaire are able to reveal something that will be measured by the questionnaire." To test the validity, the 2 tailed significance value is seen compared to 0.05 provided that:

1) Jif the 2 stringed significance value $<0.05$, then the instrument is valid,

2) Jif the 2 stringed significance value $>0.05$, then the instrument is invalid,

From the test results, it is obtained that each item statement for all variables obtained a 2 tailed significance value of $0.000<0.05$, thus the instrument is valid.

The next test is the reliability union. The reliability test analysis model used in this study is the Alpha Cronbach model. According to Ghozali (2013), "reliability is a tool for testing the consistency of respondents' answers to the questions in the questionnaire. A questionnaire is said to be reliable if a person's answer to a question is consistent or stable over time". The measurement is done by using Cronbach's Alpha analysis. Ghozali (2013) classifies the value of Cronbach's Alpha as follows:

1) If the Cronbach's Alpha value is $>0.60$, it is declared reliable,

2) If the value of Cronbach's Alpha $<0.60$, it is declared unreliable,

The test results are as follows:

Table 1. Reliability Testing Results

\begin{tabular}{|l|c|c|c|}
\hline \multicolumn{1}{|c|}{ Variable } & $\begin{array}{c}\text { Cronbach's } \\
\text { Alpha }\end{array}$ & $\begin{array}{c}\text { Alpha Critical } \\
\text { Standard }\end{array}$ & Information \\
\hline Organizational culture (X1) & 0.763 & 0.600 & Reliable \\
\hline Organizational commitment (X2) & 0.633 & 0.600 & Reliable \\
\hline Employee Performance (Y) & 0.671 & 0.600 & Reliable \\
\hline
\end{tabular}

Based on the results of the above test, the overall variables of organizational culture (X1), organizational commitment (X2) obtained a Cronbach alpha value greater than 0.60 . Thus it is declared reliable.

\subsection{Classic Assumption Test}

The classical assumption test is intended to determine the accuracy of a data. According to Singgih Santoso (2011) "A regression model will be used to make forecasts, a good model is a model with minimal forecast errors". Therefore, a model before it is used should satisfy several assumptions, which are commonly called classical assumptions. In this research, the classical assumption test used includes: Normality Test, Multicollinearity Test, Autocorrelation Test, and Heteroscedasticity Test. The results are as follows: 


\section{a. Normality Test}

The normality test is carried out to test whether in the regression model, the dependent variable and the independent variable are normally distributed or not. The results of the normality test using the Kolmogorov-Smirnov Test are as follows:

Table 2. Kolmogorov-Smirnov Normality Results

\begin{tabular}{|c|c|c|c|c|c|c|}
\hline & \multicolumn{6}{|c|}{ Tests of Normality } \\
\hline & Statistics & df & Sig. & Statistics & $\mathrm{df}$ & Sig. \\
\hline Employee Performance (Y) & .078 & 99 & .146 & .981 & 99 & .165 \\
\hline
\end{tabular}

*. This is a lower bound of the true significance.

a. Lilliefors Significance Correction

Based on the test results in the table above, a significance value of 0.146 is obtained where the value is greater than the value of $\alpha=0.050$ or $(0.146>0.050)$. Thus, the assumption of the distribution of the equation in this test is normal.

\section{b. Multiconilierity Test}

Mutlycolinearity testing is conducted to ensure that the independent variables do not have multicollinearity or do not have a correlation effect between the variables that are determined as models in the study. The multicollinearity test is carried out by looking at the Tolerance Value and Variance Inflation Factor (VIF). The test results are as follows:

Table 3. Multicollinearity Test Results with Collinierity Statistic.

\begin{tabular}{|c|c|c|c|c|c|}
\hline \multirow[b]{2}{*}{ Model } & \multicolumn{2}{|c|}{$\begin{array}{c}\text { Coefficientsa } \\
\text { Unstandardized } \\
\text { Coefficients } \\
\end{array}$} & \multirow{2}{*}{$\begin{array}{c}\begin{array}{c}\text { Standardized } \\
\text { Coefficients }\end{array} \\
\text { Beta }\end{array}$} & \multicolumn{2}{|c|}{$\begin{array}{l}\text { Collinearity } \\
\text { Statistics }\end{array}$} \\
\hline & $\mathrm{B}$ & Std. Error & & Tolerance & VIF \\
\hline $\begin{array}{ll}1 & \text { (Constant) }\end{array}$ & 9,612 & 2,924 & & & \\
\hline Organizational culture (X1) & .326 & .073 & .378 & .698 & 1,433 \\
\hline $\begin{array}{l}\text { Organizational } \\
\text { commitment }(\mathrm{X} 2)\end{array}$ & .442 & .086 & .438 & .698 & 1,433 \\
\hline
\end{tabular}

a. Dependent Variable: Employee Performance (Y)

Based on the test results in the table above, the tolerance value for each independent variable is $0.698<1.0$ and the Variance Inflation Factor (VIF) value is $1.433<10$, thus this regression model does not occur multicollinearity.

\section{c. Autocorrelation Test}

Autocorrelation testing is used to determine whether or not there are correlation deviations between sample members. The test was carried out with the Darbin-Watson test (DW test). The test results are as follows: 
Table 4. Autocorrelation Test Results

Model Summary b

\begin{tabular}{lcccrr}
\hline Model & R & R Square & $\begin{array}{c}\text { Adjusted R } \\
\text { Square }\end{array}$ & $\begin{array}{c}\text { Std. Error of } \\
\text { the Estimate }\end{array}$ & Durbin-Watson \\
\hline 1 & $.719 \mathrm{a}$ & .517 & .507 & 2,496 & 2,047 \\
\hline a. Predictors: (Constant), Organizational commitment (X2), Organizational culture (X1) \\
b. Dependent Variable: Employee Performance (Y)
\end{tabular}

\section{d. Heteroskesdasticity Test}

Heteroscedasticity testing is intended to test whether in a regression model there is an inequality of residual variance. The test results are as follows:

Table 5. Heteroskesdasticity Test Results with Glejser Test Model

\begin{tabular}{|c|c|c|c|c|c|}
\hline \multirow[b]{3}{*}{ Model } & \multicolumn{5}{|c|}{ Coefficientsa } \\
\hline & \multicolumn{2}{|c|}{$\begin{array}{c}\text { Unstandardized } \\
\text { Coefficients }\end{array}$} & \multirow{2}{*}{$\begin{array}{c}\begin{array}{c}\text { Standardized } \\
\text { Coefficients }\end{array} \\
\text { Beta } \\
\end{array}$} & \multirow[b]{2}{*}{$\mathrm{t}$} & \multirow[b]{2}{*}{ Sig. } \\
\hline & $\mathrm{B}$ & Std. Error & & & \\
\hline 1 (Constant) & 1,221 & 1,620 & & .754 & .453 \\
\hline Organizational culture $(\mathrm{X} 1)$ & -.052 & .041 & -154 & $-1,279$ & .204 \\
\hline Organizational commitment (X2) & .073 & .047 & .186 & 1,543 & .126 \\
\hline
\end{tabular}

a. Dependent Variable: RES2

The test results using the Glejser test obtained the Sig. > 0.05. Thus regression model there is no heteroskesdasticity disorder.

\subsection{Descriptive Analysis}

In this test, it is used to determine the minimum and maximum score, mean score and standard deviation of each variable. The results are as follows:

Table 6. Descriptive Statistics Analysis Results Descriptive Statistics

\begin{tabular}{|c|c|c|c|c|c|}
\hline & $\mathrm{N}$ & $\begin{array}{l}\text { Minimu } \\
\mathrm{m}\end{array}$ & $\begin{array}{l}\text { Maximu } \\
\mathrm{m}\end{array}$ & Mean & Std. Deviation \\
\hline Organizational culture (X1) & 99 & 30 & 48 & 38.20 & 4,113 \\
\hline $\begin{array}{l}\text { Organizational } \\
\text { commitment (X2) }\end{array}$ & 99 & 30 & 45 & 38.19 & 3,522 \\
\hline Employee Performance (Y) & 99 & 31 & 46 & 38.98 & 3,554 \\
\hline Valid N (listwise) & 99 & & & & \\
\hline
\end{tabular}

Organizational culture obtained a minimum variance of 30 and a maximum variance of 48 with a mean score of 3.82 with a standard deviation of 4.113 . Organizational commitment obtained a minimum variance of 30 and a maximum variance of 45 with a mean score of 3.82 with a standard deviation of 3.522. Employee performance obtained a minimum variance of 31 and a maximum variance of 46 with a mean score of 3.89 with a standard deviation of 3.554 . 


\subsection{Verification Analysis}

This analysis aims to determine the effect of the independent variable on the dependent variable. The test results are as follows:

\section{a. Multiple Linear Regression Analysis}

This regression test is intended to determine changes in the dependent variable if the independent variable changes. The test results are as follows:

Table 7. Multiple Linear Regression Test Results

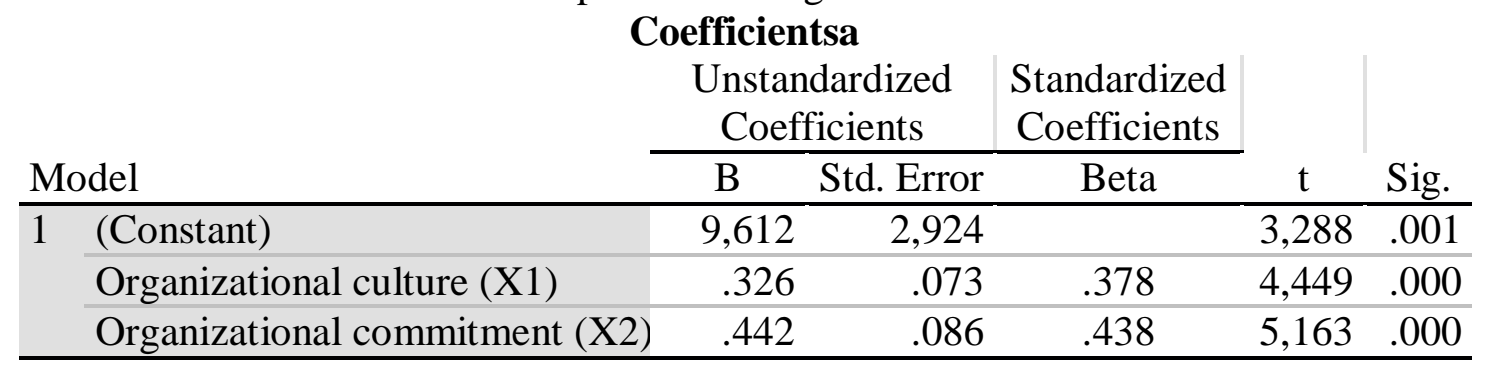

Based on the test results in the table above, the regression equation $\mathrm{Y}=9.612+$ $0.326 \mathrm{X} 1+0.442 \mathrm{X} 2$ is obtained. From this equation it is explained as follows:

1. A constant of 9.612 means that if there is no organizational culture and organizational commitment, then there is an employee performance value of 9.612 points.

2. The regression coefficient for organizational culture is 0.326 , this number is positive, meaning that every time there is an increase in organizational culture of 0.326 , the employee performance will also increase by 0.326 points.

3. The regression coefficient for organizational commitment is 0.442 , this figure is positive, meaning that every time there is an increase in organizational commitment of 0.442 , the employee's performance will also increase by 0.442 points.

\section{b. Correlation Coefficient Analysis}

Correlation coefficient analysis is intended to determine the level of strength of the relationship between the independent variable and the dependent variable either partially or simultaneously. The test results are as follows:

Table 8. Correlation Coefficient Testing Results of Organizational Culture on Employee

\section{Performance}

\section{Correlationsb}

\begin{tabular}{llr|r}
\hline & & $\begin{array}{c}\text { Quality of } \\
\text { Service (X1) }\end{array}$ & $\begin{array}{c}\text { Customer } \\
\text { Satisfaction (Y) }\end{array}$ \\
\hline Quality of Service (X1) & Pearson Correlation & 1 & $.619^{* *}$ \\
\cline { 2 - 4 } & Sig. (2-tailed) & & .000 \\
\hline Customer Satisfaction (Y) & Pearson Correlation & $.619^{* *}$ & 1 \\
\cline { 2 - 4 } & Sig. (2-tailed) & .000 & \\
\hline \multirow{2}{*}{$\begin{array}{l}* * \text { Correlation is significant at the 0.01 level (2-tailed). } \\
\text { b. Listwise N = 99 }\end{array}$} & & & \\
b. &
\end{tabular}

Based on the test results obtained a correlation value of 0.619 means that organizational culture has a strong relationship with employee performance. 
Table 9. Test Results Correlation Coefficient of Organizational Commitment to Employee Performance

Correlationsb

\begin{tabular}{llr|r}
\hline & & $\begin{array}{c}\text { Corporate } \\
\text { Image (X2) }\end{array}$ & $\begin{array}{c}\text { Customer } \\
\text { Satisfaction (Y) }\end{array}$ \\
\hline Corporate Image (X2) & Pearson Correlation & 1 & $.646^{* *}$ \\
\cline { 2 - 4 } & Sig. (2-tailed) & & .000 \\
\hline Customer Satisfaction (Y) & Pearson Correlation & $.646^{* *}$ & 1 \\
\cline { 2 - 4 } & Sig. (2-tailed) & .000 & \\
\hline \multirow{2}{*}{$\begin{array}{l}* * \text { Correlation is significant at the 0.01 level (2-tailed). } \\
\text { b. Listwise N = 99 }\end{array}$} & & & \\
\end{tabular}

Based on the test results obtained a correlation value of 0.646 means that organizational commitment has a strong relationship with employee performance.

Table 10. Results of Testing the Correlation Coefficient of Organizational Culture and Organizational Commitment simultaneously on Employee Performance.

Model Summary

\begin{tabular}{lr|r|r|r}
\hline Model & R & R Square & $\begin{array}{c}\text { Adjusted R } \\
\text { Square }\end{array}$ & $\begin{array}{c}\text { Std. Error of the } \\
\text { Estimate }\end{array}$ \\
\hline 1 & $.719 \mathrm{a}$ & .517 & .507 & 2,496 \\
\hline
\end{tabular}

a. Predictors: (Constant), Organizational commitment (X2), Organizational culture $(\mathrm{X} 1)$

Based on the test results obtained a correlation value of 0.719 means that organizational culture and organizational commitment simultaneously have a strong relationship to employee performance.

\section{c. Analysis of the Coefficient of Determination}

Analysis of the coefficient of determination is intended to determine the percentage of influence of the independent variable on the dependent variable either partially or simultaneously. The test results are as follows:

Table 11. Results of Testing the Coefficient of Determination of Organizational Culture on Employee Performance

Model Summary

\begin{tabular}{lr|r|r|r}
\hline Model & $\mathrm{R}$ & R Square & $\begin{array}{c}\text { Adjusted R } \\
\text { Square }\end{array}$ & $\begin{array}{c}\text { Std. Error of the } \\
\text { Estimate }\end{array}$ \\
\hline 1 & $.619 \mathrm{a}$ & .383 & .376 & 2,807 \\
\hline
\end{tabular}

a. Predictors: (Constant), Organizational culture (X1)

Based on the test results obtained a determination value of 0.383 means that organizational culture has an influence contribution of $38.3 \%$ on employee performance. 
Table 12. The Results of Testing the Coefficient of Determination of Organizational Commitment on Employee Performance

Model Summary

\begin{tabular}{lr|r|r|r}
\hline Model & R & R Square & $\begin{array}{c}\text { Adjusted R } \\
\text { Square }\end{array}$ & $\begin{array}{c}\text { Std. Error of the } \\
\text { Estimate }\end{array}$ \\
\hline 1 & $.646 \mathrm{a}$ & .417 & .411 & 2,727 \\
\hline
\end{tabular}

a. Predictors: (Constant), Organizational commitment (X2)

Based on the test results, it was found that the determination value was 0.417 , meaning that organizational commitment had an influence contribution of $41.7 \%$ on employee performance.

Table 13. Results of Testing the Coefficient of Determination of Organizational Culture and Organizational Commitment to Employee Performance

Model Summary

\begin{tabular}{|c|c|c|c|c|}
\hline Model & $\mathrm{R}$ & R Square & $\begin{array}{l}\text { Adjusted R } \\
\text { Square }\end{array}$ & $\begin{array}{l}\text { Std. Error of the } \\
\text { Estimate }\end{array}$ \\
\hline 1 & $.719 a$ & .517 & .507 & 2,496 \\
\hline
\end{tabular}

Based on the test results, it was found that the value of determination was 0.517 , meaning that the organizational culture and organizational commitment simultaneously had an influence contribution of $51.7 \%$ on employee performance, while the remaining $48.3 \%$ was influenced by other factors.

\section{d. Hypothesis Test}

\section{Partial Hypothesis Test (t Test)}

Hypothesis testing with the $\mathrm{t}$ test is used to determine which partial hypothesis is accepted. The first hypothesis: There is a significant influence between organizational culture on employee performance.

Table 14. Hypothesis Test Results for Organizational Culture on Employee Performance

\section{Coefficientsa}

\begin{tabular}{|c|c|c|c|c|c|}
\hline \multirow[b]{2}{*}{ Model } & \multicolumn{2}{|c|}{$\begin{array}{c}\text { Unstandardized } \\
\text { Coefficients }\end{array}$} & \multirow{2}{*}{$\begin{array}{c}\text { Standardized } \\
\text { Coefficients } \\
\text { Beta } \\
\end{array}$} & \multirow[b]{2}{*}{$\mathrm{t}$} & \multirow[b]{2}{*}{ Sig. } \\
\hline & $\mathrm{B}$ & Std. Error & & & \\
\hline 1 (Constant) & 18,556 & 2,648 & & 7,007 & .000 \\
\hline $\begin{array}{l}\text { Organizational } \\
\text { culture (X1) }\end{array}$ & .535 & .069 & .619 & 7,757 & .000 \\
\hline
\end{tabular}

a. Dependent Variable: Employee Performance (Y)

Based on the test results in the table above, the value of $t$ count $>t$ table or $(7,757>$ $1,985)$ is obtained, thus the first hypothesis proposed that there is a significant influence between organizational culture on employee performance is accepted. 
Table 15. Hypothesis Test Results Organizational Commitment to Employee Performance

\section{Coefficientsa}

\begin{tabular}{|c|c|c|c|c|c|}
\hline \multirow[b]{2}{*}{ Model } & \multicolumn{2}{|c|}{$\begin{array}{l}\text { Unstandardized } \\
\text { Coefficients }\end{array}$} & \multirow{2}{*}{$\begin{array}{c}\begin{array}{c}\text { Standardized } \\
\text { Coefficients }\end{array} \\
\text { Beta } \\
\end{array}$} & \multirow[b]{2}{*}{$\mathrm{t}$} & \multirow[b]{2}{*}{ Sig. } \\
\hline & $\mathrm{B}$ & Std. Error & & & \\
\hline $1 \quad$ (Constant) & 14,080 & 3,000 & & 4,693 & .000 \\
\hline $\begin{array}{l}\text { Organizational commitment } \\
\text { (X2) }\end{array}$ & .652 & .078 & .646 & 8,335 & .000 \\
\hline
\end{tabular}

a. Dependent Variable: Employee Performance (Y)

Based on the test results in the table above, the $t$ value> $t$ table or $(8.335>1.985)$ is obtained, thus the second hypothesis that is proposed that there is a significant influence between organizational commitment on employee performance is accepted.

\section{Simultaneous Hypothesis Test (Test F)}

Hypothesis testing with the F test is used to determine which simultaneous hypothesis is accepted. The third hypothesis There is a significant influence between organizational culture and organizational commitment to employee performance.

Table 16. Hypothesis Test Results Organizational Culture and Organizational Commitment to Employee Performance

\section{ANOVAa}

\begin{tabular}{llrrrrr}
\hline \multicolumn{1}{l}{ Model } & Sum of Squares & df & Mean Square & F & Sig. \\
\hline 1 & Regression & 639,936 & 2 & 319,968 & 51,364 & $.000 \mathrm{~b}$ \\
\cline { 2 - 7 } & Residual & 598,024 & 96 & 6,229 & & \\
\cline { 2 - 7 } & Total & 1237,960 & 98 & & & \\
\hline
\end{tabular}

a. Dependent Variable: Customer Satisfaction (Y)

b. Predictors: (Constant), Company Image (X2), Service Quality (X1)

Based on the test results in the table above, the value of $\mathrm{F}$ count> $\mathrm{F}$ table or $(51,364>$ $2,700)$ is obtained, thus the third hypothesis proposed that there is a significant influence between organizational culture and organizational commitment to employee performance is accepted.

\subsection{The Influence of Organizational Culture on Employee Performance}

From the analysis, it was found that organizational culture variables had a significant effect on employee performance with a correlation value of 0.619 , meaning that the two variables had a strong relationship with an influence contribution of 38.3\%. Hypothesis testing obtained $t$ value $>t$ table or $(7,757>1,985)$. Thus the first hypothesis proposed that there is a significant effect between organizational culture on employee performance is accepted.

\subsection{The Effect of Organizational Commitment on Employee Performance}

From the analysis, it was found that the organizational commitment variable had a significant effect on employee performance with a correlation value of 0.646 , meaning that the two variables had a strong relationship with an influence contribution of $41.7 \%$. Hypothesis testing obtained $t$ value $>t$ table or $(8.335>1.985)$. Thus, the second hypothesis proposed that there is a significant effect between organizational commitment and employee performance is accepted. 


\subsection{The Influence of Organizational Culture and Organizational Commitment on Employee Performance}

From the analysis, it was found that the variable organizational culture and organizational commitment had a significant effect on employee performance with the regression equation $\mathrm{Y}=9.612+0.326 \mathrm{X} 1+0.442 \mathrm{X} 2$, the correlation value was 0.719 , meaning that the two variables had a strong relationship with an influence contribution of $51.7 \%$ while the rest $48.3 \%$ influenced by other factors. Hypothesis testing obtained the value of $\mathrm{F}$ count $>\mathrm{F}$ table or $(51,364>2,700)$. Thus the third hypothesis proposed that there is a significant effect between organizational culture and organizational commitment to employee performance is accepted.

\section{Conclusion}

The conclusion can be drawn as follows:

1. Organizational culture has a significant effect on employee performance with a correlation value of 0.619 or strong with an influence contribution of $38.3 \%$. Hypothesis testing obtained $t$ value $>t$ table or $(7,757>1,985)$. Thus there is a significant influence between organizational culture on employee performance at the Ministry of Manpower of the Republic of Indonesia.

2. Organizational commitment has a significant effect on employee performance with a correlation value of 0.646 or strong with a contribution of influence of $41.7 \%$. Hypothesis testing obtained $t$ value $>t$ table or (8.335> 1.985). Thus there is a significant influence between organizational commitment on employee performance at the Ministry of Manpower of the Republic of Indonesia.

3. Organizational culture and organizational commitment have a significant effect on employee performance with a correlation value of 0.719 or strong with an influence contribution of $51.7 \%$ while the remaining $48.3 \%$ is influenced by other factors. Hypothesis testing obtained the value of $F$ count $>F$ table or $(51,364>2,700)$. Thus there is a significant influence between organizational culture and organizational commitment simultaneously on employee performance at the Ministry of Manpower of the Republic of Indonesia.

The suggestion are: 1) The Ministry of Manpower of the Republic of Indonesia needs to maintain and instill a better organizational culture, especially in maintaining the tradition of cooperation between employment agencies so that there is a concerted effort in maintaining the spirit of the institution. 2) The Ministry of Manpower of the Republic of Indonesia needs to increase its organizational commitment, especially in providing optimal services to the community so as to create an institution that works in a professional and accountable manner. 3) The Ministry of Manpower of the Republic of Indonesia needs to improve overall performance so that it becomes an institution that is able to help the government realize the best possible distribution of labor 


\section{References}

Algifari. (2015). "Regression Analysis for Business and Economics". Yogyakarta: BPFE.

Arif, Syamsul. (2019). Influence of Leadership, Organizational Culture, Work Motivation, and Job Satisfaction of Performance Principles of Senior High School in Medan City. Budapest International Research and Critics Institute (BIRCI-Journal), 239-254.

Arikunto, Suharsimi (2014). "Research Procedure, A Practice Approach". Jakarta: Rineka Cipta.

Australia. Hie translation. B. Prawira. Human Resource Management. Four Salemba. Jakarta.

Dewi, K. (2015). The Influence of Work Ethics, Incentives and Career Development on Employee Performance at the Cutting Department of PT Morichindo Fashion Ungaran. Among Makarti.8 (16): 56-62.

Edi Sutrisno (2016). Human Resource Management. Jakarta: Prenadamedia Group.

Freed Luthans (2016) Organizational Behavior, McGraw-Hill, New York.

Gerry Dessler (2016) Human Resources Management, Prenticehall, London: International Inc.

Griffin RW, \& Ronald, JE (2003). Marketing Basics. Jakarta: King

Hadion Wijoyo, Denok Sunarsi. (2020). International Management. CV. Independent Cendekia Person, Jakarta

Handoko (2016) Personnel and Human Resources Management. Yogyakarta: BPFE.

Hasibuan (2016) "Human Resource Management". Haji Masagung. Jakarta.

Hasibuan, MSP 2008. Human Resource Management. PT Bumi Aksara. Jakarta.

Henry Simamora (2005), Human Resource Management, STIE YKPN Bandung.

Imam Ghozali (2017). "Multivariate Analysis Application with SPSS Program".Fifth Edition. Semarang: Undip Publishing Agency.

Istijanto (2014) "Human Resources Research". Jakarta: PT. Gramedia Pustaka Employee Performance at the Manado Ratumbuysang Hospital. Emba Journal. 1 (4): 646-656 Study Performance on Employees of Sidorejo District, Salatiga City. Among Makarti. 3 (5): 18-33.

Mangkunegara, AP (2011). Company Human Resource Management. Youth Rosdakarya Offset. Bandung.

Mangkunegara, Anwar Prabu. (2008). "Company Human Resource Management, first printing". Publisher: Remaja Rosdakarya, Bandung

Marwansyah. (2010). Human Resource Management. Edition 2. Alfabeta. Bandung.

Mathis, RL and Jackson. 2009. Human Resource Management. 10th Ed. South-Western.

Octarina, A. (2013). The Influence of Work Ethic and Work Discipline on Employee Performance at the Department of Culture, Tourism, Youth and Sports, Sarolangun Regency. Collection of Student Journal of the Faculty of Economics, University of Andalas. 1 (1): 1

Posuma, CO. (2013). The Influence of Competence, Compensation and Leadership on

Pranoto, P., Jasmani, J., \& Marayasa, IN (2019). Digital Marketing Training for Economic Improvement of the Members of the Al Barkah Youth Organization in Cicayur Village, Tangerang. Journal of Pengabdian Dharma Laksana, 1 (2), 250-258.

Prasada, D., Sunarsi, D., \& Teriyan, A. (2020). The Effect of Work Ethics and Compensation on Organizational Commitment at DHL Logistics in Jakarta. JENIUS (Scientific Journal of Human Resource Management), 4 (1), 51-60

Rivai Veithzal (2015) Human Resource Management for Companies. Publisher PT Raja Grafindo Persada, Jakarta, 2010. 
Robbins, S. P and TA Judge. (2008). Organizational Behavior. 13th Ed. PHI Learning Private Limited. New Delhi. B. Molan translation. 2009. Organizational Behavior. Edition 16. Salemba Empat. Jakarta.

Santoso, Singgih (2015). "Mastering Multivariate Statistics". Jakarta: PT Elex Media Komputindo.

Sedarmayanti (2016) Human Resource Management, Bureaucratic Reform and Civil Service Management, Fifth Printing, Bandung: PT Refika Aditama.

Sedarmayanti. (2013). Human Resource Management, Bureaucratic Reform and Civil Servant Management. Refika Aditama. Bandung.

Siagian, S (2007). Human Resource Management. Jakarta: Earth Literacy. Sinamo, J. (2011). Eight Professional Work Ethics. Jakarta: Institute

SInamo, J. 2005. Eight Professional Work Ethics. Mahardika Institute. Jakarta.

Sudjana (2014) "Statistical Methods", Bandung: Tarsido.

Sugiyono (2017), "Administrative Research Methods: equipped with R \& D Methods". Bandung: Alfabeta.

Sulasmi, E. (2020). The Development Strategy of Human Resources Management In Children's Social Welfare Institution (LKSA) (Case Study in LKSA AL-Mubaraak Orphanage Bengkulu). Budapest International Research and Critics Institute-Journal (BIRCI-Journal). P. 562-569.

Sunarsi, D. (2017). The Influence of Leadership and Organizational Culture on Employee Performance at Bank DKI Pondok Labu-South Jakarta Sub Branch. JENIUS, 1 (2), 21.

Sunarsi, D. (2018). Strategic Human Resource Development \& Characteristics of Support Systems: An Overview. MEA Scientific Journal (Management, Economics, \& Accounting), 2 (3), 178 - 194.

Sunarsi, D. (2019). Application of Strategic HRM in an Effort to Improve Organizational Capabilities in facing the 4.0 Revolution. MEA Scientific Journal (Management, Economics, \& Accounting), $3 \quad$ 221233.https://doi.org/10.31955/mea.vol3.iss1.pp221-233

Sunarsi, D., \& Asmalah, L. (2018). Personal Development Management Training for UGM RZIS Scholarship Recipients and Shalahuddin Wallet, Jogjakarta. Journal of Pengabdian Dharma Laksana, 1 (1), 51-60.

Sutrisno, E. (2011). Human Resource Management. Kencana Prenada Media Group. Jakarta.

Sutrisno, S., \& Sunarsi, D. (2019). The Effect of Work Motivation and Discipline on Employee Productivity at PT. Anugerah Agung in Jakarta. Journal of Ad'ministrare, 6 (2), 187-196.

Tolentino, RC (2013). Organizational Commitment and Job Performance of the Academic and Administrative Personnel. International Journal of Information Technology and Business Management. 15 (1): 51-60.

Werdhiastutie, A. et al. (2020). Achievement Motivation as Antecedents of Quality Improvement of Organizational Human Resources. Budapest International Research and Critics Institute-Journal (BIRCI-Journal). P. 747-752.

Yuangga, KD, \& Sunarsi, D. (2018). The Influence of Procrastination and Low Time Management on Student Self Efficacy (at MA Soebono Mantofani). PINISI Discretion Review, 2 (1), 85-92. 